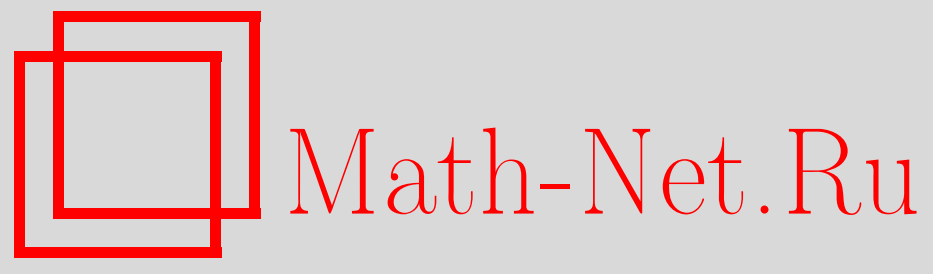

P. T. Museibli, O влиянии электростатического поля на динамику расширения газовых пузырьков, Вестн. Сам. гос. техн. ун-та. Сер. Физ.мат. науки, 2019, номер 4, 756-763

DOI: https://doi.org/10.14498/vsgtu1717

Использование Общероссийского математического портала MathNet.Ru подразумевает, что вы прочитали и согласны с пользовательским соглашением

http://www.mathnet.ru/rus/agreement

Параметры загрузки:

IP: 3.91 .87 .62

26 апреля 2023 г., 13:40:22

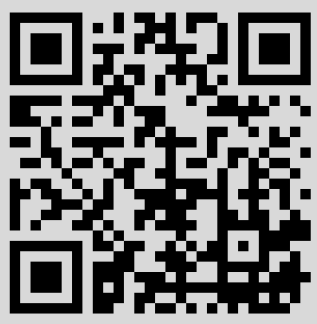




\title{
On the electrostatic field in expansion dynamics of gas bubbles
}

\section{P. T. Museibli}

Institute of Mathematics and Mechanics, Azerbaijan National Academy of Sciences, 9, F. Agaev st., Baku, AZ1141, Azerbaijan.

\begin{abstract}
The work is devoted to the study of the dynamics of the formation of bubbles in a gas-liquid system taking into account the potential difference. The electrical conductivity of the fluid is determined depending on the concentration of the electrolyte and, accordingly, the electrostatic field that occurs when the fluid flows. The effect of the electrostatic field on the bubble formation dynamics has shown that the radius of the gas bubbles and the dynamics of its expansion, formed by the pressure difference, can be regulated by the potential difference parameter.

Depending on the electrolytic concentration, the electric conductivity of the liquid and, accordingly, the electrostatic field arising from friction in fluid are determined. The effect of the electrostatic field on the dynamics of the bubble formation has shown that the radius of gas bubbles and expansion dynamics formed by the pressure drop can be regulated by the potential difference parameter. It is presented that one of the main factors affecting the flow of two-phase fluids is the nature of the liquid phase and the concentration of electrolyte added. The results of regulation of the bubble formation dynamics in the gas-liquid system via the electrostatic field and a number of physical parameters can be applied in the oil and gas industry, chemical processes, biomechanics.
\end{abstract}

Keywords: gas bubble, electrostatic field, pressure drop, potential difference, expansion dynamics.

Received: $1^{\text {st }}$ July, 2019 / Revised: $4^{\text {th }}$ September, $2019 /$

Accepted: $11^{\text {th }}$ November, $2019 /$ First online: $9^{\text {th }}$ December, 2019

\section{Short Communication}

() (1) The content is published under the terms of the Creative Commons Attribution 4.0 International License (http://creativecommons.org/licenses/by/4.0/)

Please cite this article in press as:

Museibli P. T. On the electrostatic field in expansion dynamics of gas bubbles, Vestn. Samar. Gos. Tekhn. Univ., Ser. Fiz.-Mat. Nauki [J. Samara State Tech. Univ., Ser. Phys. Math. Sci.], 2019, vol. 23, no. 4, pp. 756-763. doi: 10.14498/vsgtu1717.

\section{Author's Details:}

Parviz T. Museibli (1) https://orcid.org/0000-0002-5133-7581

Junior Researcher; Dept. of Fluid Mechanics; e-mail: pervizmuseyibli@gmail.com 
Introduction. Bubbling and its expansion dynamics are the major components of a wide range of chemical, environmental processes and fluid, especially, oil mechanic. Bubbles generally have broad size distributions and complex property variations over time too [1-3]. Although changing of bubbles forms in gas-liquid systems can seem to be a simple phenomenon, it actually involves complex dynamical interactions. Characteristically, in gas-liquid systems, small bubbles have effective role at the interphase heat and mass transfer. Here, it is important to control bubble sizes and extensions.

Dynamics of the gas bubbles formation in liquids and viscous-elastic fluids has been studied for quite a long time [4]. Bubbling has been the topic of numerous studies [5-9]. Two main phenomena have been determined for bubble formation in the electric fields under electrical voltage of electrohydrodynamic flow: electrical voltage is directly present in the gas-liquid interphase and is directed inward. Under conditions of electrohydrodynamic flow, a significant decrease of nozzle pressure is caused by voltage increasing [10]. Because of the effects of electrostatic potential and pressure difference, the interaction effects of the bubble expansion dynamics are more complicated and important, so this is the subject of present research.

In [11], the authors have experimentally investigated the effects of electrostatic potential on the bubble dynamics, and tried to determine the value of the electrical potential used to control the process.

The results reflect that bubble formation dynamics have nonlinear dependence with increasing applied potential at the constant flow rate and bubble frequency increases as increasing voltage. Authors have shown also that external physics fields (electric, magnetic, etc.) should be used due to achieve more significant effects.

In [12], authors have established adiabatic two-phase flows by injecting gas (nitrogen) bubbles into a liquid (FC-72) separating mechanical effects from thermal and mass exchange ones in order to investigate effects of external electric fields on the bubble dynamics. Here is mainly investigated the effect of the electric field on the detachment frequency and velocity of bubbles. Other parameters (bubble shape and its oscillations, typical trajectory of a single bubble) are currently under study, both in normal and microgravity environments.

In [13], author considered formation of bubble in a rigid and elastic hole, taking into account the surface tension and obtained some meaningful results. Various surface active substances (SAM) have been used to control the surface tension. For the rigid hole, to study the relation between $d_{B}$ (bubble diameter) and $U_{O F}$ (flow velocity) for the different liquid phases. Firstly, for a hole gas velocity above $6 \mathrm{~m} / \mathrm{s}$, the effect of liquid surface tension on the bubble diameter have been investigated. The bubble diameter is significantly lower below $6 \mathrm{~m} / \mathrm{s}$ in water solutions with surface active substances (SAM).

The lowest bubble diameters occur in solution of non-ionic surfactant $\left(\sigma_{L}=\right.$ $30.4 \mathrm{mN} / \mathrm{m})$, then in the anionic surfactant solution $\left(\sigma_{L}=40.7 \mathrm{mN} / \mathrm{m}\right)$ and the cationic surfactant solution $\left(\sigma_{L}=27.4 \mathrm{mN} / \mathrm{m}\right)$; the butanol aqueous solution $\left(\sigma_{L}=62.6 \mathrm{mN} / \mathrm{m}\right)$ has no effect on the formation of bubbles [13]. These results limit the conception of static surface tension: the smallest bubbles are not formed with the liquid phase which has the lowest static surface tension [13].

To achieve better results we need to measure dynamic surface tension. To 
investigate the relation between $d_{B}$ and $U_{O F}$ for the different liquid phases three general terms can be formulated for the flexible holes:

1) the bubble diameters are significantly reduced over the whole hole gas velocity range in comparison with water;

2) as with water the bubble diameter presents a less, than linear increase with velocity;

3) a special phenomenon occurs below $3 \mathrm{~m} / \mathrm{s}$, which did not exist in water: the bubble jet is divided into two jets.

Using the geometric characteristics of the apparatus and bearing in mind the nature of liquid, the surface tension of the solution for a given bubble formation time can be defined [14,15]. By changing the concentration of surface active substances (SAM), it is possible to regulate the surface tension.

Authors [16] investigated the effect of time-variant temperature on the dynamics of a single gas bubble in a liquid. With changes in temperature, different physical parameters regulating bubble formations change including surface tension, diffusivity, vapour pressure and gas solubility. A single-bubble model formulated and a numerical simulation implemented to model the radius-time prole of a bubble, taking into account the above-mentioned parameter.

According to studies, Henry constant and diffusion coefficient depending on the temperature are included to the model. It is important in determining the bubble expansion process at any temperature field.

1. Materials and methods. In all of the above mentioned studies, the dynamics of bubbles in gas-liquid systems at $\Delta p$ pressure difference, regulation of bubble radius and expansion dynamics by various physical parameters were studied. Similar problems have also been studied by many researchers applying the external electricity field. In contrast, the effect of the electrostatic field, arising during flow (the potential difference parameter) on the bubble radius and expansion dynamics were studied. Studies have shown that the radius of bubbles gradually decreases when the value of potential difference increases [17].

Taking into account the studies of the gas bubbles dynamics through various physical parameters, a regulation of process of bubble formation through the potential difference parameter was considered in present work. In spherical coordinates, a single bubble model was formulated to investigate the effects of electrostatic field on bubble expansion in fixed thermobaric conditions.

The following assumptions have been made to construct the model:

- bubble always remains spherical and allows the problem considering in a single dimension;

- temperature and pressure inside and outside of the bubble is stable.

2. Problem solution. The Rayleigh-Plesset equation is used to model the effect of electrostatic field on the change of bubble radius $R$ with time $t$ in fixed thermobaric conditions:

$$
R \frac{d^{2} R}{d t^{2}}+\frac{3}{2}\left(\frac{d R}{d t}\right)^{2}+\frac{2}{3} \frac{\sigma E^{2}}{\rho_{m}} R \frac{d R}{d t}+2 \frac{\Sigma}{R}=\frac{p_{q}-p_{m}}{\rho_{m}} .
$$

Here $R$ is the radius of the bubble; $E$ - electrostatic field; $\Sigma$ - the surface tensile coefficient; $\sigma$ - electrical conductivity, $\rho_{m}$ - the density of the liquid phase, and $p_{q}, p_{m}$ - respectively, the pressure of the gas and liquid. 
Note that the electrostatic field formed by friction in the liquid is defined as follows

$$
e=\Delta \varphi=\varphi_{1}-\varphi_{2} .
$$

Here gas pressure is expressed as follows

$$
\frac{d p_{2}}{d t}=-3 \gamma \frac{p_{2}}{R} \omega_{R}
$$

First, the dynamics of formation of gas bubbles at different values of the $\Delta p$ pressure difference (at the smallest values of potential difference) were investigated. The equation (1) is solved by the Runge-Kutta numerical method, $\Delta \varphi=0.5 \mathrm{mV}, \Sigma=0.0002 \mathrm{~N} / \mathrm{m}$ (Fig. 1).

The expansion radius of bubbles increases as the pressure difference increases. Then, this equation was solved by changing the potential difference in the constant value of the pressure drop $\Delta p$, and the following results were obtained (Figs. 2 and 3$)$.

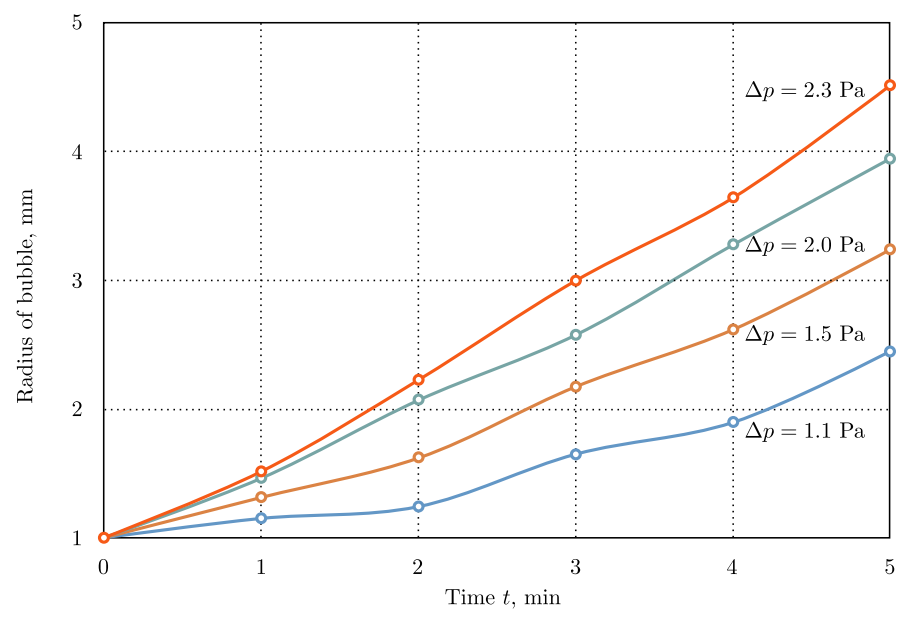

Figure 1. Radius of bubble vs. time under different pressure drop

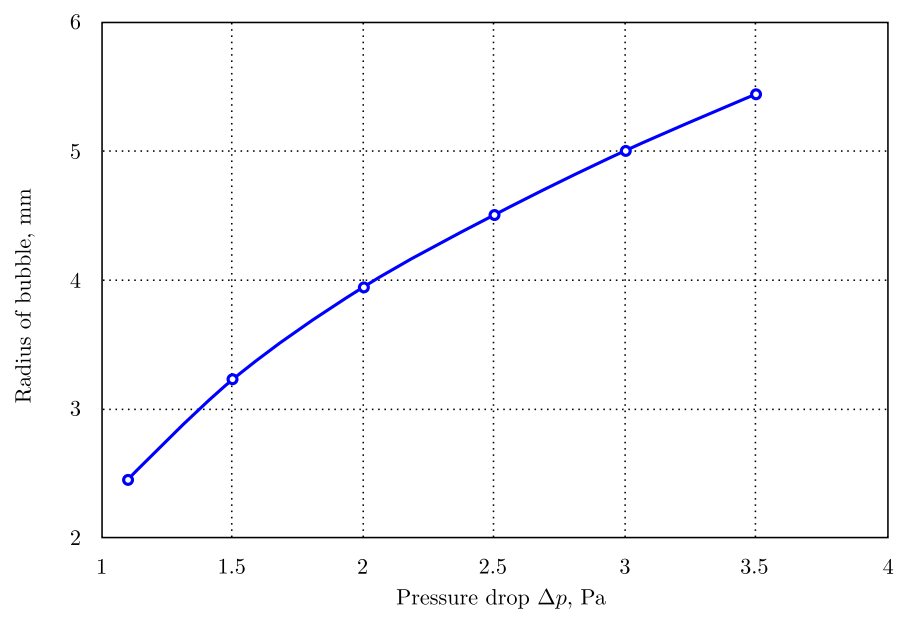

Figure 2. Radius of bubble vs. pressure drop 


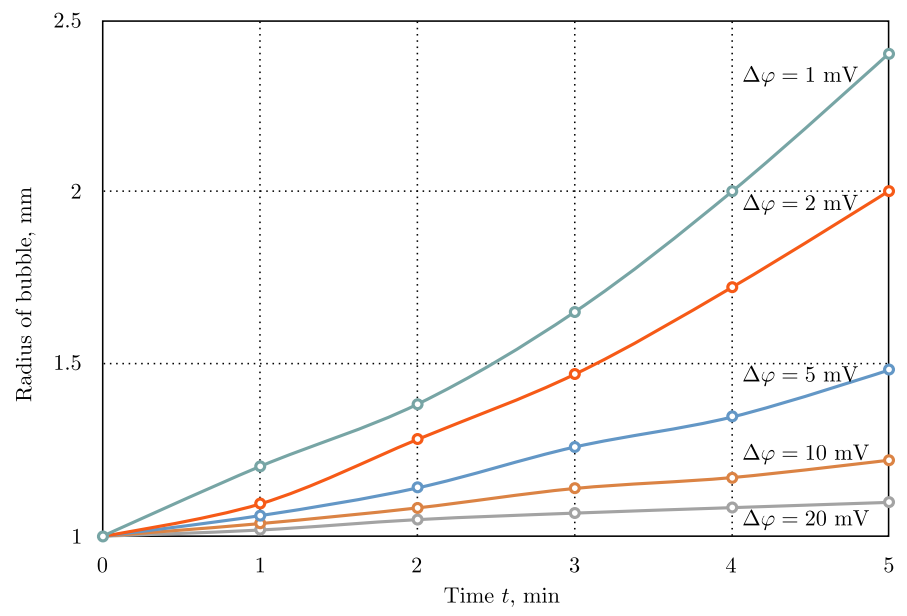

Figure 3. Radius of bubble vs. time under different electric potential differences

On the contrary, we can see from this that as the value of potential difference increases, the radius of the bubble decreases gradually. Given all this, it was found that the formation of gas bubbles under certain values of pressure difference can be regulated by the potential difference parameter

3. Methods. In [17], the electrical conductivity of the fluid under different concentrations of electrolytes is investigated. Depending on the concentration of electrolytes the value of potential difference arising in the fluid at different flow rates was determined. Considering the values of parameters obtained at the dynamic equation of bubble, we show the possibility of regulating expansion radius.

That is, the value of the potential difference in aqueous solutions of $0.1 \%$ $\mathrm{NaCl}$ (in a constant value of pressure difference) has been determined. The results obtained when regulating the dynamics of bubble formation through the potential difference parameter are shown in Fig. 4.

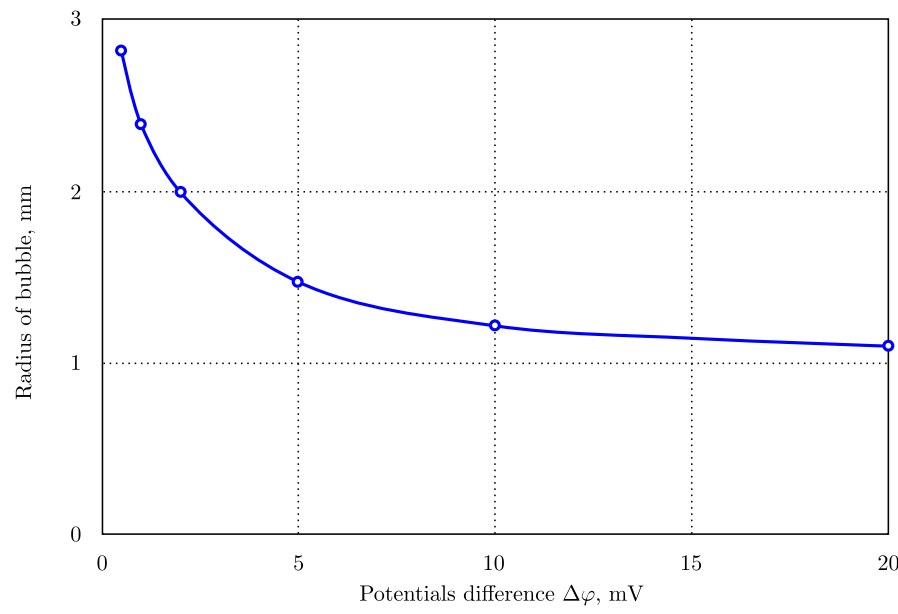

Figure 4. Dependence of bubble radius in aqueous solutions with $0.1 \%$ electrolyte vs. potentials difference 
4. Results. In this research, the dynamics of bubble formation in the gasliquid system was studied, taking into account the potential difference parameter. In experiments the aqueous solution of $\mathrm{NaCl}$ was investigated.

Depending on the electrolytic concentration, the electric conductivity of the liquid and, accordingly, the electrostatic field arising from friction in fluid are determined. The effect of the electrostatic field on the dynamics of the bubble formation showed that the radius of gas bubbles and its expansion dynamics formed by the pressure drop can be regulated by the potential difference parameter (Fig. 5). For this purpose, we must focus mainly on the nature of the liquid phase and concentration of the added electrolyte.

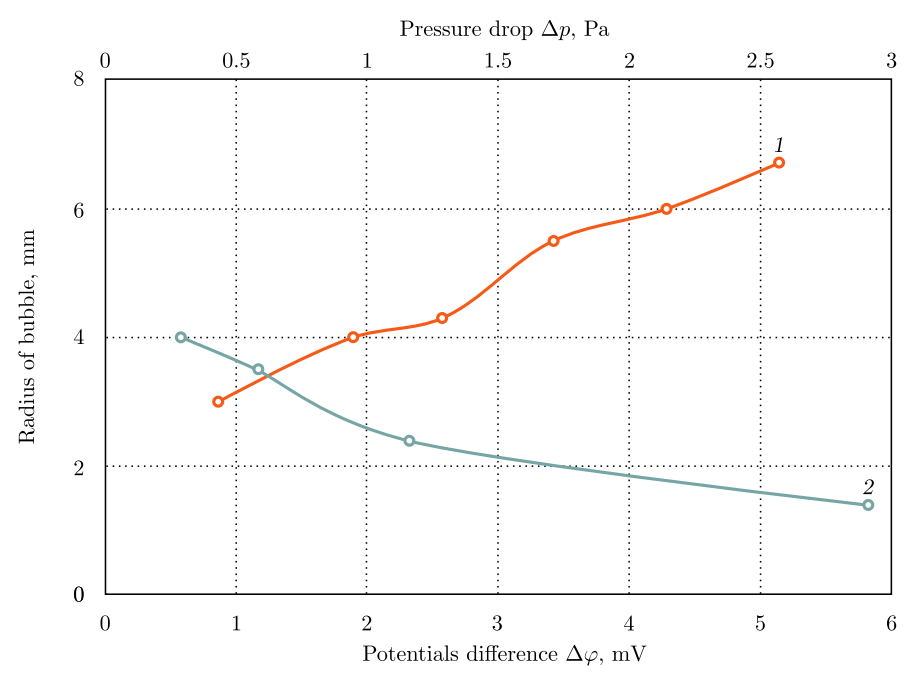

Figure 5. Dependence of bubble radius vs. pressure drop and potential difference

The results of regulation of the bubble formation dynamics in the gas-liquid system via the electrostatic field and a number of physical parameters can be applied in the oil and gas industry, chemical processes, biomechanics.

Competing interests. I have no competing interests.

Author's Responsibilities. I take full responsibility for submitting the final manuscript in print. I approved the final version of the manuscript.

\section{References}

1. Femat R., Alvarez-Ramírez J., Soria A. Chaotic flow structure in a vertical bubble column, Phys. Lett. A, 2018, vol. 248, no. 1, pp. 67-79. doi: 10.1016/S0375-9601(98)00506-4.

2. Kikuchi R., Yano T., Tsutsumi A. et al. Diagnosis of chaotic dynamics of bubble motion in a bubble column, Chem. Eng. Sci., 1997, vol.52, no. 21-22, pp. 3741-3745. doi: 10.1016/ s0009-2509(97)00220-0.

3. Luewisutthichat W., Tsutsumi A., Yoshida K. Chaotic hydrodynamics of continuous singlebubble flow systems, Chem. Eng. Sci., 1997, vol.52, no.21-22, pp. 3685-3691. doi: 10 . 1016/s0009-2509(97)88927-0.

4. Lord Rayleigh O.M. F.R.S. On the pressure developed in a liquid during the collapse of a spherical cavity, The London, Edinburgh, and Dublin Philosophical Magazine and Journal of Science, 1917, vol.34, no. 200, pp. 94-98. doi : 10.1080/14786440808635681.

5. Tsuge H. Hydrodynamics of bubble formation from submerged orifices, In: Encyclopedia of Fluid Mechanics, vol. 3. Houston, TX, Gulf Publ., 1986, pp. 191-232. 
6. Deshpande D. A., Deo M. D., Hanson F. V., Oblad A. G. A model for the prediction of bubble size at a single orifice in two-phase gas-liquid systems, Chem. Eng. Sci., 1991, vol. 47, no. 7, pp. 1669-1676. doi : 10.1016/0009-2509(92)85014-3.

7. Longuet-Higgins M. S., Kerman B. R., Lunde K. The release of air bubbles from an underwater nozzle, J. Fluid Mech., 1991, vol.230, pp. 365-390. doi : 10.1017/S0022112091000836.

8. Drahoš J., Bradka F., Punčochář M. Fractal behaviour of pressure fluctuations in a bubble column, Chem. Eng. Sci., 1992, vol.47, no. 15-16, pp. 4069-4075. doi: 10.1016/ 0009-2509 (92) 85158-8.

9. Terasaka K., Tsuge H. Bubble formation under constant-flow conditions, Chem. Eng. Sci., 1993, vol. 48, no. 19, pp. 3417-3422. doi : 10.1016/0009-2509 (93) 80159-n.

10. Tsouris C., Shin W.-T., Yiacoumi S. Pumping, spraying, and mixing of fluids by electric fields, Canad. J. Chem. Eng., 1998, vol.76, no.3, pp. 589-599. doi:10.1002/cjce. 5450760331.

11. Sarnobat S. U., Rajput S., Bruns D. D. et al. The impact of external electrostatic fields on gas-liquid bubbling dynamics, Chem. Eng. Sci., 2004, no. 1, pp. 247-258. doi: 10.1016/j . ces.2003.09.001.

12. Danti M., Di Marco P., Grassi W., Memoli G. Effect of an external electric field on bubble dynamics: Preliminary study, In: Proc. XVIII UIT National Conference (Cernobbio, 28-30 June 2000), 2000, pp. 715-728, http://www2.ing.unipi.it/ a006600/papers/ uit0obolle-f.pdf.

13. Loubière K., Hébrard G. Influence of liquid surface tension (surfactants) on bubble formation at rigid and flexible orifices, Chem. Eng. Process., 2004, vol.43, no.11, pp. 1361-1369. doi : 10.1016/j.cep.2004.03.009.

14. Tauzin C. Contribution à l'étude et à la recherche d'applications spécifiques de la technique de fractionnement par bulles, Thesis dissertation no. 23. INSA Toulouse France, 1979 (In French).

15. Loubière K. Croissance et détachement de bulles générées par des orifices rigides et flexibles dans des phases liquides newtoniennes: étude expérimentale et modélisation, Thesis dissertation no. 663. INSA Toulouse France, 1979 (In French).

16. Webb I. R., Arora M., Roy R.A. et al. Dynamics of gas bubbles in time-variant temperature fields, J. Fluid Mech., 2010, vol.663, pp. 209-232. doi : 10.1017/S0022112010003472.

17. Panahov G. M., Museibli P. T. The study of internal exposure on the fluid hydrodynamics, Transactions of NAS of Azerbaijan, Issue Mechanics, 2017, vol. 37, no. 7, pp. 66-71. 
Вестн. Сам. гос. техн. ун-та. Сер. Физ.-мат. науки. 2019. Т. 23, № 4 . С. $756-763$

ISSN: 2310-7081 (online), 1991-8615 (print)

dol https://doi.org/10.14498/vsgtu1717

УДК 532.529

\title{
О влиянии электростатического поля на динамику расширения газовых пузырьков
}

\author{
P. T. Museibli \\ Institute of Mathematics and Mechanics, \\ Azerbaijan National Academy of Sciences, \\ 9, F. Agaev st., Baku, AZ1141, Azerbaijan.
}

\begin{abstract}
Аннотация
Работа посвящена изучению динамики образования пузырьков в газожидкостной системе с учетом разности потенциалов. Электропроводность жидкости определяется в зависимости от концентрации электролита и, соответственно, от электростатического поля, возникающего при течении жидкости. Влияние электростатического поля на динамику образования пузырьков показало, что радиус пузырьков газа и динамика его расширения вследствие изменения перепада давления зависят от разности потенциалов протекания.

В зависимости от концентрации электролита определяется электрическая проводимость жидкости и, соответственно, электростатическое поле, возникающее в результате трения в жидкости. Влияние электростатического поля на динамику образования пузырьков показало, что радиус пузырьков газа и динамика его расширения, образованная падением давления, могут регулироваться параметром разности потенциалов. Показано, что одним из основных факторов, влияющих на течение двухфазных жидкостей, является природа жидкой фазы и концентрация электролита. Результаты регулирования динамики образования пузырьков в газожидкостной системе посредством электростатического поля и ряда физических параметров могут быть применены в процессах нефтегазовой отрасли, химического производства, биомеханике.
\end{abstract}

Ключевые слова: газовый пузырек, электростатическое поле, перепад давления, разность потенциалов, динамика расширения.

Получение: 1 июля 2019 г. / Исправление: 4 сентября 2019 г. Принятие: 11 ноября 2019 г. / Публикация онлайн: 9 декабря 2019 г.

\section{Краткое сообщение}

( )(7) Контент публикуется на условиях лицензии Creative Commons Attribution 4.0 International (https://creativecommons.org/licenses/by/4.0/deed.ru)

\section{Образец для цитирования}

M u seibli P. T. On the electrostatic field in expansion dynamics of gas bubbles, Vestn. Samar. Gos. Tekhn. Univ., Ser. Fiz.-Mat. Nauki [J. Samara State Tech. Univ., Ser. Phys. Math. Sci.], 2019, vol. 23, no. 4, pp. 756-763. doi: 10.14498/vsgtu1717.

\section{Сведения об авторе}

Parviz T. Museibli (10) https://orcid.org/0000-0002-5133-7581

Junior Researcher; Dept. of Fluid Mechanics; e-mail: pervizmuseyibli@gmail.com 